\title{
Induction of neural crest cells from mouse embryonic stem cells in a serum-free monolayer culture
}

\author{
YUKO AIHARA ${ }^{1}$, YOHEI HAYASHI ${ }^{1}$, MITSUHI HIRATA ${ }^{2}$, NOBUTAKA ARIKI ${ }^{3}$, SHINSUKE SHIBATA ${ }^{4}$, \\ NARIHITO NAGOSHI ${ }^{4,5}$, MIO NAKANISHI ${ }^{1}$, KIYOSHI OHNUMA ${ }^{1}$, MASAKI WARASHINA ${ }^{6}$, TATSUO MICHIUE ${ }^{1}$, \\ HIDEHO UCHIYAMA ${ }^{7}$, HIDEYUKI OKANO ${ }^{4}$, MAKOTO ASASHIMA ${ }^{1,8}$ and MIHO KUSUDA FURUE*,2
}

\begin{abstract}
${ }^{1}$ Department of Life Sciences (Biology), Graduate School of Arts and Sciences, University of Tokyo, Tokyo, ${ }^{2}$ Laboratory of Cell Cultures, Department of Disease Bioresources, National Institute of Biomedical Innovation, Osaka, ${ }^{3}$ Department of Biological Sciences, Graduate School of Science, The University of Tokyo, Tokyo, ${ }^{4}$ Department of Physiology, Keio University, School of Medicine, Tokyo, ${ }^{5}$ Department of Orthopedic Surgery, Keio University, School of Medicine, Tokyo, ${ }^{6}$ Cell Biology Research Center, Genome Research Laboratories, Wako Pure Chemical Industries, Ltd., Hyogo, ${ }^{7}$ International Graduate School of Arts and Sciences, Yokohama City University, Yokohama and ${ }^{8}$ Research Center for Stem Cell Engineering, National Institute of Advanced Industrial Science and Technology (AIST), Ibaraki, Japan
\end{abstract}

\begin{abstract}
The neural crest (NC) is a group of cells located in the neural folds at the boundary between the neural and epidermal ectoderm. NC cells differentiate into a vast range of cells, including neural cells, smooth muscle cells, bone and cartilage cells of the maxillofacial region, and odontoblasts. The molecular mechanisms underlying NC induction during early development remain poorly understood. We previously established a defined serum-free culture condition for mouse embryonic stem (mES) cells without feeders. Here, using this defined condition, we have developed a protocol to promote mES cell differentiation into NC cells in an adherent monolayer culture. We found that adding bone morphogenetic protein (BMP)-4 together with fibroblast growth factor (FGF)-2 shifts mES cell differentiation into the NC lineage. Furthermore, we have established a cell line designated as P0-6 that is derived from the blastocysts of P0-Cre/Floxed-EGFP mice expressing EGFP in an NC-lineage-specific manner. P0-6 cells cultured using this protocol expressed EGFP. This protocol could be used to help clarify the mechanisms by which cells differentiate into the NC lineage and to assist the development of applications for clinical therapy.
\end{abstract}

KEY WORDS: neural crest, embryonic stem cell, defined serum-free condition, BMP-4

\section{Introduction}

Embryonic stem (ES) cells (Evans and Kaufman, 1981; Martin, 1981) have the potential to generate all differentiated cell types in vitro. ES cells are therefore an amenable model of mammalian development for biochemical and molecular analyses (Gardner and Brook, 1997; Smith, 2001; Tanaka et al., 2002). Mouse ES cells (mES) are commonly cultured on inactivated primary mouse embryonic fibroblasts in culture medium supplemented with serum and leukemia inhibitory factor (LIF), whereby ES cells can maintain their cell self-renewal (Smith et al., 1988; Williams et al., 1988). Withdrawal of LIF stimulates spontaneous differentiation of mES cells in serum-containing culture media, and culturing protocols have been developed to drive the differentiation of $\mathrm{mES}$ cells into certain cell types. However, these procedures require the cultivation of cell aggregates (Wiles and Johansson, 1999), medium containing serum or undisclosed supplements (Lake et al., 2000), or animal-derived feeder cells (Kawasaki et al., 2000). Serum contains variable and undefined amounts of soluble growth and differentiation factors as well as extracellular components such as fibroblast growth factors (FGFs), bone morphogenetic proteins (BMPs), fibronectin, and laminin; thus the presence of serum could cloud our understanding of the mechanisms of cell differentiation. By the same token, feeder cells and undisclosed supplements might also hamper the analysis.

Abbreviations used in this paper: BMP, bone morphogenetic protein; FGF, fibroblast growth factor; mES, mouse embryonic stem cell; NC, neural crest.

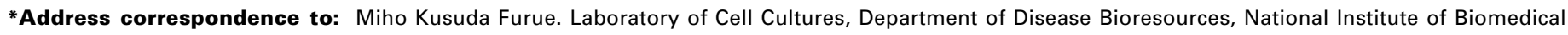
Innovation, 7-6-8, Saito-Asagi, Ibaraki-shi, Osaka 567-0085 Japan. Fax: +81-72-641-9851. e-mail: mkfurue@nibio.go.jp
}

Supplementary Material for this paper (figure + table) is available at: http://dx.doi.org/10.1387/ijdb.103173ya 
The neural crest (NC) is a group of cells located in the neural folds at the boundary between the neural and epidermal ectoderm. During the process of neurulation, NC cells in the dorsal ridges of the neural tube in vertebrates become widely distributed within the developing embryo after a phase of extensive migration. The NC cells differentiate into a vast range of cells, including neurons and glial cells of the autonomic and enteric nervous systems, smooth muscle cells of the heart and large vessels, bone and cartilage cells of the maxillofacial region, and odontoblasts (Le Douarin and Dupin, 2003). Because NC cells are an indistinct and transient population, the mechanisms of NC development are generally difficult to analyze. Our previous studies in Xenopusindicated that the developmental fate of undifferentiated cells can be controlled by concentration-sensitive inducing factors, such as activin A and BMP-4 (Asashima et al., 2000; Tremblay etal., 2000; Tiedemann etal., 2001; Furue and Asashima, 2004). Although several protocols have been developed for deriving NC cells from ES cells, these usually involve forming embryoid bodies or culturing in medium that contains undefined components (Mizuseki et al., 2003; Kawaguchi et al., 2005; Zhou and Snead, 2008; Lee et al., 2010). Therefore, a need exists for a protocol using a defined serum-free medium for differentiating $\mathrm{NC}$ cells from mES cells in a monolayer culture based on knowledge of the cellular responses to specific growth factors.

We previously described several serum-free media suitable to propagate and accurately analyze the characteristics of differentiated cells (Hayashi and Sato, 1976; Furue and Saito, 1998; Sato et al., 2002; Furue et al., 2008). One of these media, ESF7, supports the serial cultivation of undifferentiated mES cells in the absence of feeder cells and thus provides an experimental system for elucidating developmental responses to specific environmental stimuli (Furue et al., 2005; Hayashi et al., 2010). Indeed, the effect of LIF on mES cells was revealed using this culture condition. We also developed a serum-free medium for culturing human ES cells without feeder cells (Furue et al., 2008). Another serum-free culture medium, ESF5, can be used to detect the effects of growth factors on mES cell differentiation (Furue et al., 2005). In this study, with the aim of further understanding the mechanisms of NC development, we have developed a new culture protocol for inducing NC cell differentiation from mES cells under defined monolayer culture conditions. Our results showed that BMP-4 together with FGF-2 induced mES cells to differentiate into NC cells.

\section{Results}

\section{Effect of ECM on neuronal progenitor differentiation}

To first establish a suitable matrix upon which mES cells could be differentiated into neural cell lineages, we investigated the effects of extracellular matrix components (ECMs), type I collagen, laminin, fibronectin and poly-D-lysine (PDL) on mES cell differentiation in our ESF5 medium developed for mES cell differentiation (Furue et al., 2005). Undifferentiated mESCs were transferred onto the various ECMs for culturing in ESF5 medium supplemented with FGF-2 and heparin, but without LIF. We found that many cells died on type I collagen and on PDL, but the cells on laminin grew efficiently. Then, we determined the growth rate of the cells cultured on the various ECMs. The cells grew at a higher growth rate on laminin than cells cultured on the other ECMs (Fig. 1A). TUNEL assays were also performed to determine whether the cells underwent apoptotic cell death (Fig.1 B,D). The proportion of apoptotic cells was approximately $80 \%$ in cultures plated on type I collagen or PDL, and $<20 \%$ on laminin or fibronectin. Mouse ES cells cultured on laminin or fibronectin in ESF5 with FGF-2 also exhibited a neural cell-like morphology. The extent of neural cell differentiation was then analyzed by immunostaining for expression of the neuronal progenitor marker, Nestin (Lendahl et al., 1990) using an anti-Nestin antibody (Fig. $1 \mathrm{C}, \mathrm{D})$. On laminin or fibronectin, $>70 \%$ of the cells were Nestinpositive, while on type I collagen or PDL, less than $20 \%$ of the differentiating mES cells showed Nestin expression. The cells cultured on type I collagen or PDL underwent cell death without

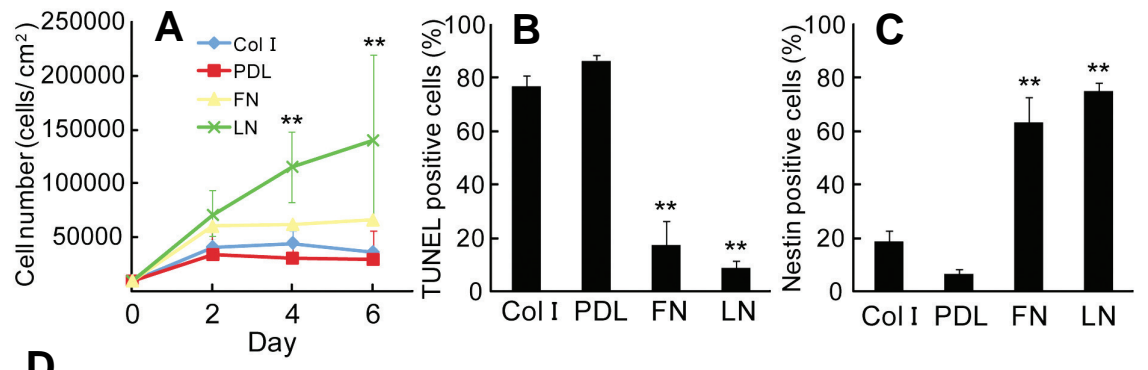

D
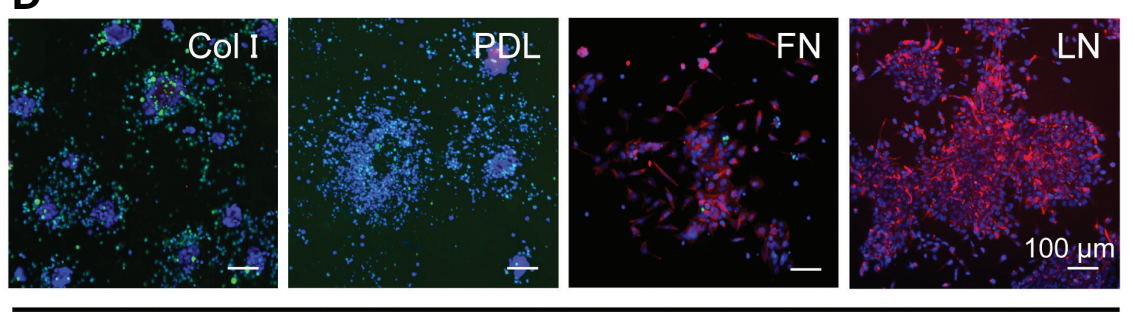

TUNEL / Nestin / DAPI
Fig. 1. The effect of adhesion molecules on mES cell survival and differentiation. Mouse ES cells were cultured in ESF5 with $10 \mathrm{ng} / \mathrm{ml}$ FGF-2 on collagen I $\left(15 \mu \mathrm{g} / \mathrm{cm}^{2}\right)$, poly-D-lysine $\left(2 \mu \mathrm{g} / \mathrm{cm}^{2}\right)$, fibronectin $\left(2 \mu \mathrm{g} / \mathrm{cm}^{2}\right)$, or laminin $\left(2 \mu \mathrm{g} / \mathrm{cm}^{2}\right)$. (A) Proliferation of mES cells on various ECM components. Mouse ES cells were seeded in a 24-well plate coated with each ECM at $5 \times 10^{3}$ cells perwell. Cells were counted every 24 hours. The values are mean $\pm \operatorname{SEM}(n=4)$. ${ }^{*} \mathrm{P}<$ 0.01 compared with Day 0. (B) Percentage of TUNELpositive cells. Percentages were calculated from the observation of more than 350 cells for each sample. The values are mean \pm SEM $(n=5) .{ }^{*} P<0.01$ compared with Col I, PDL. (C) Percentages of Nestinpositive cells. Mouse ES cells were cultured on chamber slides coated with each ECM components. Nestin expression was detected using anti-Nestin antibody. Percentages were calculated from the observation of more than 350 cells for each sample. The values are mean \pm SEM $(n=5) . *{ }^{*} P<0.01$ compared with Coll, PDL. (D) Double staining with TUNEL (green) and anti-Nestin antibody (red). After the TUNEL assay, the cells were immunostained with anti-Nestin antibody. Nuclei were stained with DAPI (blue). Scale bars, $100 \mu \mathrm{m}$. Abbreviations: Col I, type I collagen; FN, fibronectin; LN, laminin; PDL, poly-D-lysine. 
differentiation, whereas the cells cultured on laminin or fibronectin differentiated into neural progenitor cells without marked cell death (Fig. 1D). These results suggested that laminin is effective for the differentiation of mES cells into neural lineages under defined serum-free culture conditions. Accordingly, we used a laminin matrix for cell culturing in subsequent experiments.

\section{Effect of FGF-2 on neural cell lineage differentiation}

We next examined the effect of FGF-2 on neural marker gene expression in mES cells cultured in ESF5 on laminin for 6 days (Fig. 2). Real-time PCR analysis showed an increased expression of Nestin and Musashi1 (Sakakibara et al., 1996), which are neural stem/progenitor cell (NSPC) markers, after 4 days in culture. The expression of a post-mitotic neuron marker, microtubule-associated protein 2 (MAP2) (DeCamilli et al., 1984), was also increased at 4 days. These results suggested that FGF-2 induces $\mathrm{mES}$ cells to differentiate into neural progenitors after 4 days of culture. The expressions of NC marker genes, Snailand Slug were also increased at 6 days of culture, but a more precise NC marker, $A P-2 \alpha$, was not increased in this culture condition. These results indicated that FGF-2 induced neural lineage differentiation in mES cells, but was not sufficient to generate NC cells.

\section{Effect of growth factors on cell differentiation into NC cells}

During development, the cells in the neural tube differentiate into NC cells, and we suspected that an unknown factor might act to shift the differentiation of neuroepithelial cells down the NC pathway. We thus searched for a factor which, when used in combination with FGF-2, would efficiently induce expression of $A P-2 \alpha$ in the FGF-2-induced neural lineage cells. The mES cells were cultured in ESF5 with FGF-2 for 2 days, and then further cultured with various additional factors. Among the growth factors examined here, BMP-4 efficiently and dose-dependently increased $A P$-2 $\alpha$ expression after 2 days in culture compared to cells cultured in ESF5 with either FGF-2 alone or FGF2 with the other growth factors tested (Fig. 3 A,B). However, many epithelial cells appeared in the BMP4 + FGF-2 culture conditions, as shown by immunocytochemical staining for an epithelial cell marker, pancytokeratin (Fig. 3C). We proposed that addition of BMP-4 to the mES cells after only 2 days in culture with FGF-2 alone could induce the residual undifferentiated cells to differentiate into other cell lineages. To test this, we added the BMP-4 into the culture after 4 days of culturing with FGF-2. The levels of $A P-2 \alpha$ expression were higher in the cells that were treated with BMP-4 after the 4-day-culture with FGF-2 (Fig. 3 $D, E)$ compared to those treated with BMP-4 after the 2-day-culture with FGF-2, and the expression of pancytokeratin was less prominent (Fig. 3 C,F). AP-2 $\alpha$ protein was also detected by immunolocalization in cells cultured with BMP-4 for 10 days after being cultured with FGF-2 for 4 days (Fig. 3G). We then confirmed that expression of the undifferentiated mouse ES cell markers Oct3/4, Nanog, and SSEA-1 disappeared by 4 days of culture from the starting day (Fig. $3 \mathrm{H})$. These results suggested that the combination of BMP-4 and FGF-2 could promote the differentiation of ES cells into NC cells.

\section{Characterization of the induced NC cells}

To confirm whether the cells induced by treatment with FGF2 and BMP-4 were indeed NC cells, we examined the expression of NC marker genes Slug, Snail, Twist, Sox9, Sox10, and Pax3in the induced cells using real-time RT-PCR analysis. All of these marker genes were strongly upregulated in the induced cells from undifferentiated cells (Fig. 4A). We also examined the expression of the NC stem cell markers P0 (Fig. 4B) and p75 (Fig. 4C) in the induced cells by immunocytochemistry. Both proteins were detected in the cultured cells. Together, these experiments indicated that the induced cells were NC cells.

Finally, to determine whether the induced NC cells had the potential to differentiate into NC derivatives, we attempted to drive the in vitro differentiation of NC cells into peripheral neurons, Schwann cells, and smooth muscle cells. Since NC cells may also be a mesenchymal stem cell precursor (Morikawa et al., 2009a, b), we additionally examined the in vitrodifferentiation of induced NC cells into adipocytes, chondrocytes, and osteocytes. When the induced NC cells were cultured in ESF5 medium with FGF-2 and BMP-4 for an additional 4 days, the cells showed a morphology typical of neural-like cells and became immunopositive for A2B5 and O4, suggesting a glial cell lineage (Fig. 5 A,B). On the other hand, induced NC cells cultured in ESF5 medium with FGF2, BMP-4, and PDGF for 7 additional days showed morphology similar to Schwann cells and expressed Krox-20 protein, a marker of Schwann cells (Fig. 5C). Real-time RT-PCR analysis confirmed the increased Krox-20at the gene expression level in the induced cells (Supplementary Fig. 1). When the induced NC cells were cultured in ESF5 medium with FGF-2 alone for 4 more days, the cells became spindle-shaped and became immunopositive for peripherin staining as a marker of peripheral neurons (Fig. 5D). When the induced NC cells were cultured in Dulbecco's modified Eagle's medium (DMEM) containing $10 \%$ fetal calf serum for
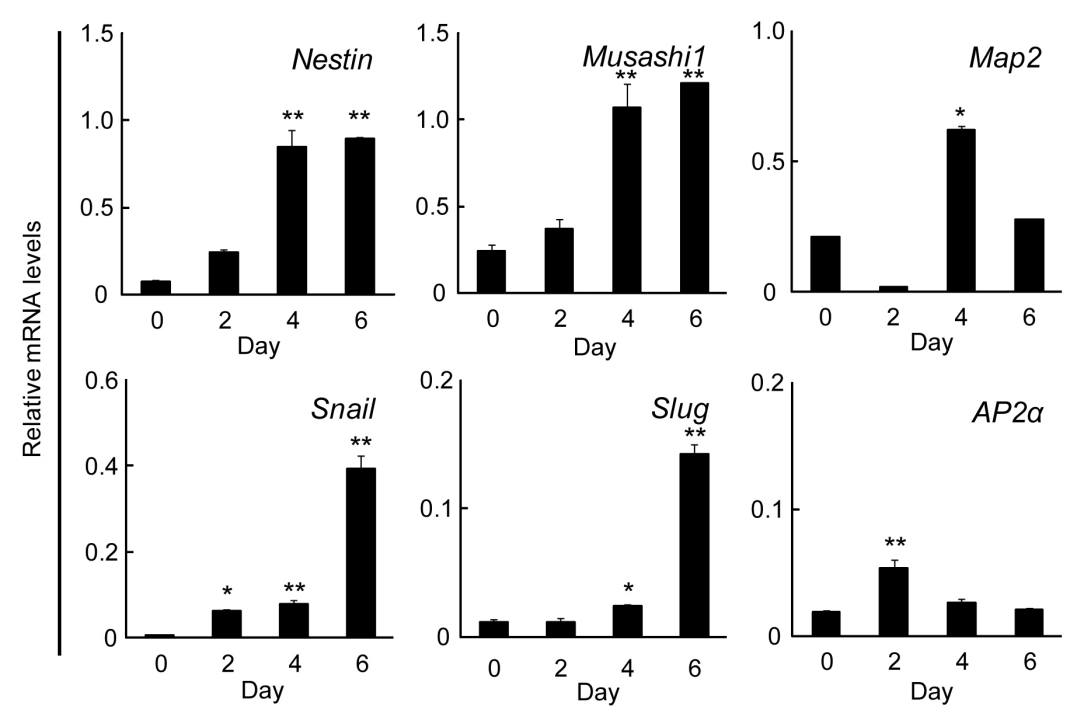

Fig. 2. The effect of FGF-2 on neural marker gene expression in mES cells. The expression of neural and NC cell markers in mES cells cultured with $10 \mathrm{ng} / \mathrm{ml} \mathrm{FGF}-2$ in ESF5 on laminin for 6 days. The expressions were normalized to gapdh $m R N A$, and the $m R N A$ levels in the cells were expressed relative to those in mouse whole embryos at E10.5, which was taken as 1 . The values are mean $\pm S E M(n=5)$. ${ }^{*} P<0.05,{ }^{*} P$ $<0.01$ compared with Day 0. 
Fig. 3. The effect of growth factors with FGF-2 on NC cell marker expression in mES cells. $(A, B, C)$ The cells were cultured in ESF5 + FGF-2 $(10 \mathrm{ng} / \mathrm{ml})$ supplemented with the indicated growth factors after the treatment with $10 \mathrm{ng} / \mathrm{ml}$ FGF-2 in ESF5 on laminin for 2 days. (A) Expression of an NC cell marker, AP-2 $\alpha$, in the cells cultured with the indicated growth factors at $10 \mathrm{ng} / \mathrm{ml}$. The relative mRNA expression level to $m E S$ cells treated with LIF was determined by real-time PCR. The values are the mean $\pm S E M(\mathrm{n}=3)$. (B) The effect of BMP-4 concentration on AP- $2 \alpha$ expression in the cells. The cells were treated with BMP-4 at the indicated concentrations. The $m R N A$ expression level relative to that of undifferentiated mES cells was determined by real-time PCR. (C) Pan-cytokeratin expression in the cells treated with $10 \mathrm{ng} / \mathrm{ml}$ BMP-4. (D,E,F) The cells were cultured with growth factors in ESF5 $+10 \mathrm{ng} / \mathrm{ml}$ FGF-2 after treatment with $10 \mathrm{ng} / \mathrm{ml} \mathrm{FGF-2} \mathrm{in} \mathrm{ESF5} \mathrm{on}$ laminin for 4 days. (D) AP-2 $\alpha$ expression in the cells cultured with the indicated growth factors. The mRNA expression level relative to that in mES cells treated with LIF was determined by real-time PCR. (E) AP-2 $\alpha$ expression in the cells cultured with $10 \mathrm{ng} / \mathrm{m} / \mathrm{BMP}-4$. The relative $m R N A$ expression level to that in undifferentiated mES cells was determined by real-time PCR. (F) Pan-cytokeratin expression in the cells cultured with $10 \mathrm{ng} / \mathrm{ml}$ $B M P-4$. (G) Cell morphology and $A P-2 \alpha$ expression of the cells during the differentiation process. Undifferentiated mES cells (Day 0) were replated into laminin in ESF5 with $10 \mathrm{ng} / \mathrm{ml}$ FGF-2, and then cultured for 4 days (Day 4). Then, the cells were further cultured with $10 \mathrm{ng} / \mathrm{ml} \mathrm{BMP-4}$ in ESF5 + FGF-2 for 2 days (Day 6) or for 4 days (Day 10). The cells were stained with anti-AP-2 $\alpha$ (green) and the nuclei were stained with DAPI (blue). (H) Undifferentiated mES marker expression during the differentiation process. The cells were stained with anti-Oct3/4, anti-Nanog, and anti-SSEA-1 antibodies at culture day 0,2 , and 4 . The nuclei were stained with DAPI (blue). The values are the mean \pm SEM (n $=3$ ) in all the graphs. ${ }^{*} \mathrm{P}<0.05,{ }^{*} \mathrm{P}<0.01$ compared with the control. Scale bars: $100 \mu \mathrm{m}$.

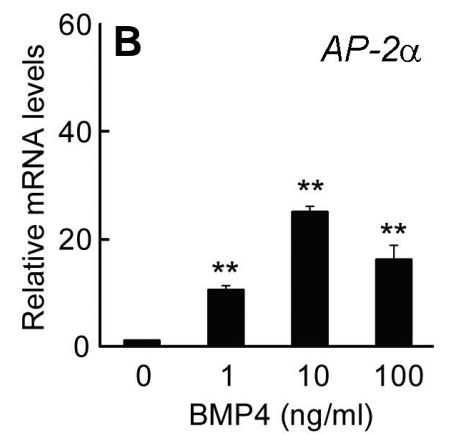

Cytokeratin/DAPI
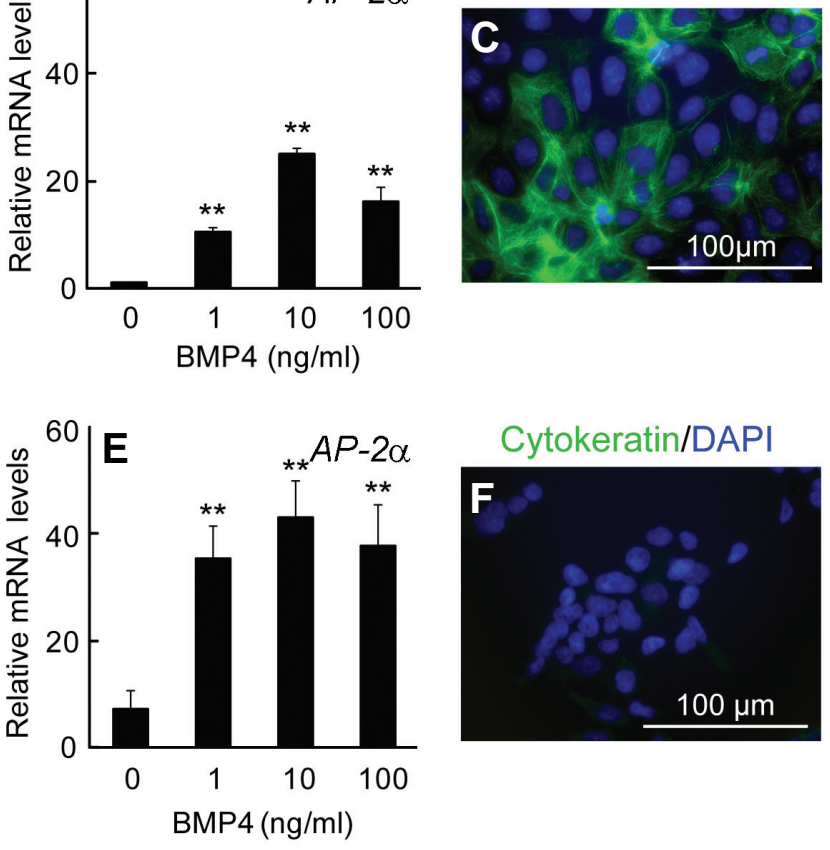

Cytokeratin/DAPI

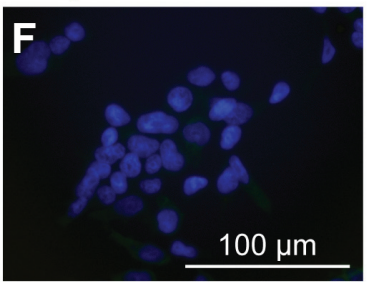

Day4

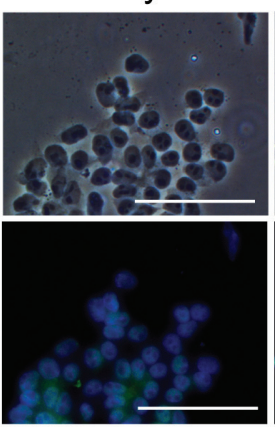

Day6

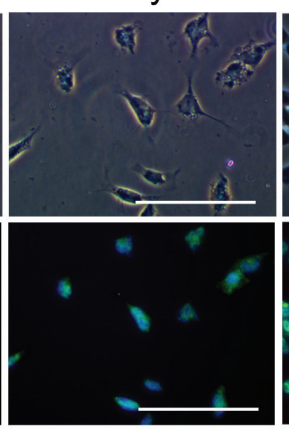

Day10

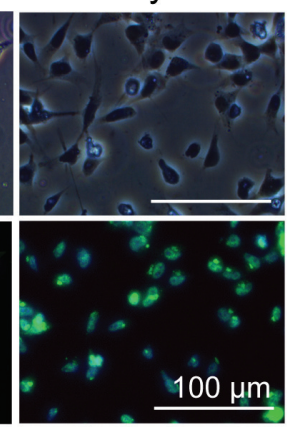

Day4
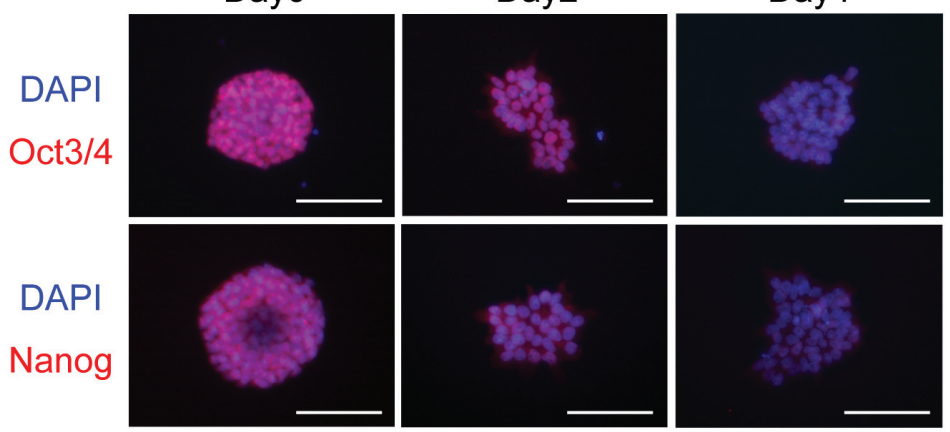

DAPI

SSEA1
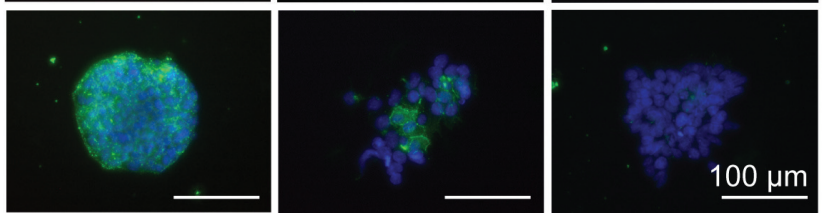


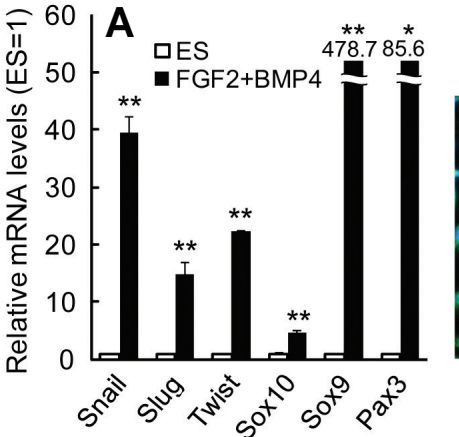

more than 4 days, smooth muscle actin-positive cells appeared (Fig. 5E).

When the induced NC cells were cultured in chondrocyte differentiation medium, cell aggregates appeared that stained positive with Alcian blue (Fig. 5F) and anti-type II collagen antibody, suggesting that the cells had differentiated into chondrocytes (Fig. 5G). On the other hand, culturing in osteoblast differentiation medium induced the formation of nodules that stained positive with Alizarin Red S (Fig. $5 \mathrm{H}$ ) and with anti-type I collagen and/or Hoxa2 antibodies (Fig. 5I), suggesting an osteoblast lineage. When the induced NC cells were cultured in adipocyte differentiation medium, Oil red O-positive cells appeared (Fig. 5J). Taken together, these results suggested that the induced NC cells could differentiate into different NC derivatives.

\section{ES cells derived from PO promoter-Cre/CAG-CATloxP/--EGFP mice}

Nagoshi et al. (2008) reported the retrieval of NC-derived cells from adult tissues using anti-GFP antibody in $\mathrm{PO}$ promoter-Cre and CAG-CAT ${ }^{\mathrm{loxP} /}$-EGFP double transgenic mice. Based on this, we tried to establish an ES cell line derived from blastocysts of P0Cre/CAG-CAT ${ }^{\mathrm{loxP}} /$-EGFP mice and started as primary cultures on feeder cells in ESF7 medium (LIF 2000 unit/ml) supplemented with $5 \%$ fetal bovine serum (FBS). ES cell-like cells appeared from the explanted blastocysts. Clone 6 showed the best growth

Fig. 5 (Right). Ability of the induced NC cells to differentiate into NC derivatives. (A,B,C) Differentiation into Schwann cells was induced in ESF5 medium supplemented with $10 \mathrm{ng} / \mathrm{ml} \mathrm{FGF-2} \mathrm{and} 10 \mathrm{ng} / \mathrm{ml} \mathrm{BMP-4}$ for 4 days. (A) Cells immunostained with A2B5 antibody (green). (B) Cells stained with anti-O4 antibody (green). (C) The cell differentiation was induced in ESF5 medium supplemented with $10 \mathrm{ng} / \mathrm{m} / \mathrm{FGF}-2,10 \mathrm{ng} /$ $\mathrm{mlBMP}-4$, and $10 \mathrm{ng} / \mathrm{ml}$ PDGF for 7 days. The cells were immunostained with anti-Krox-20 antibody (green). (D) Peripheral nerve differentiation induced in ESF5 medium supplemented with $10 \mathrm{ng} / \mathrm{ml}$ FGF-2 for 4 days. The cells were immunostained with anti-peripherin antibody (green). (E) Smooth muscle differentiation was induced in DMEM supplemented with 10\% FCS for 4 days. The cells were immunostained with anti-SMA antibody (green). (F,G) Chondrocytic differentiation of the induced NC cells was induced in chondrogenic medium for 8 days. (F) The aggregation of differentiated cells was stained with Alcian blue (b/ue). (G) The section of aggregation was positively immunostained for anti-collagen II

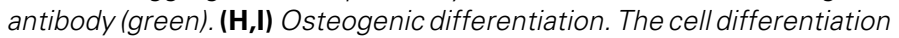
was induced in osteogenic medium for 8 days. (H) The nodules were stained with Alizarin Red S (red) (I), and were immunostained with antiHoxa2 (green) and anti-collagen I antibodies (red). (J) Adipocyte differentiation was induced in adipogenic medium for 25 days. The cells were stained by Oil red O staining (red). The nuclei were stained with DAPI (blue). Scale bars: $100 \mu \mathrm{m}$.
Fig. 4. Neural Crest (NC) cell marker expression in the induced NC cells. Mouse ES cells were treated with the culture protocol established for NC cell differentiation. (A) Gene expression in the induced NC cells. The mRNA expression level relative to that in undifferentiated $m E S$ cells was determined by real-time PCR. The values are mean \pm SEM $(n=3)$. ${ }^{*} P<0.05,{ }^{*} P<0.01$ compared with undifferentiated $\mathrm{mES}$ cells. (B) PO protein expression in the induced NC cells. (C) $P 75$ protein expression in the induced NC cells. Nuclei were stained with DAPI (blue). Scale bars: $100 \mu \mathrm{m}$.
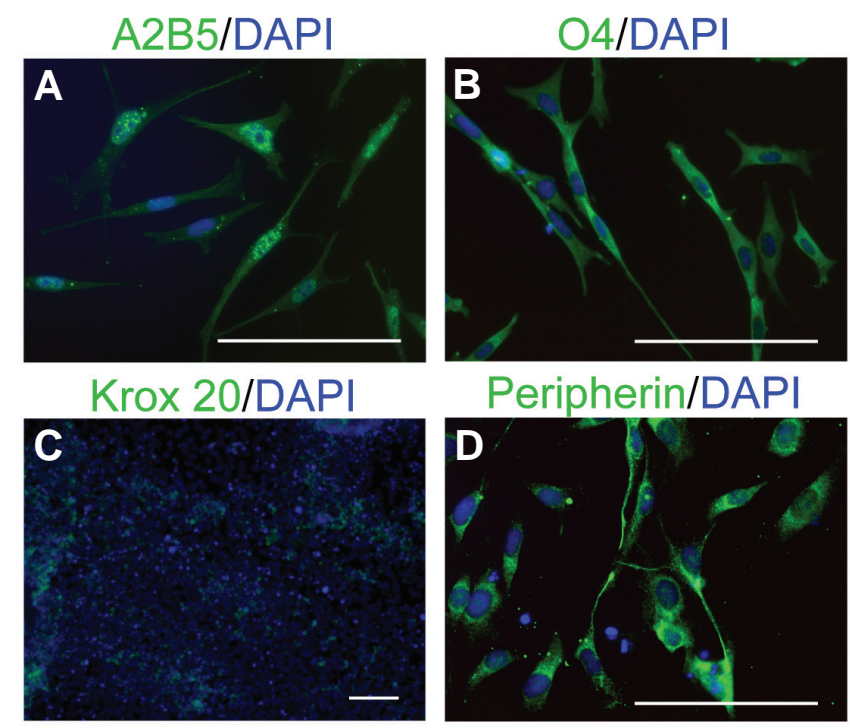

Peripherin/DAPI
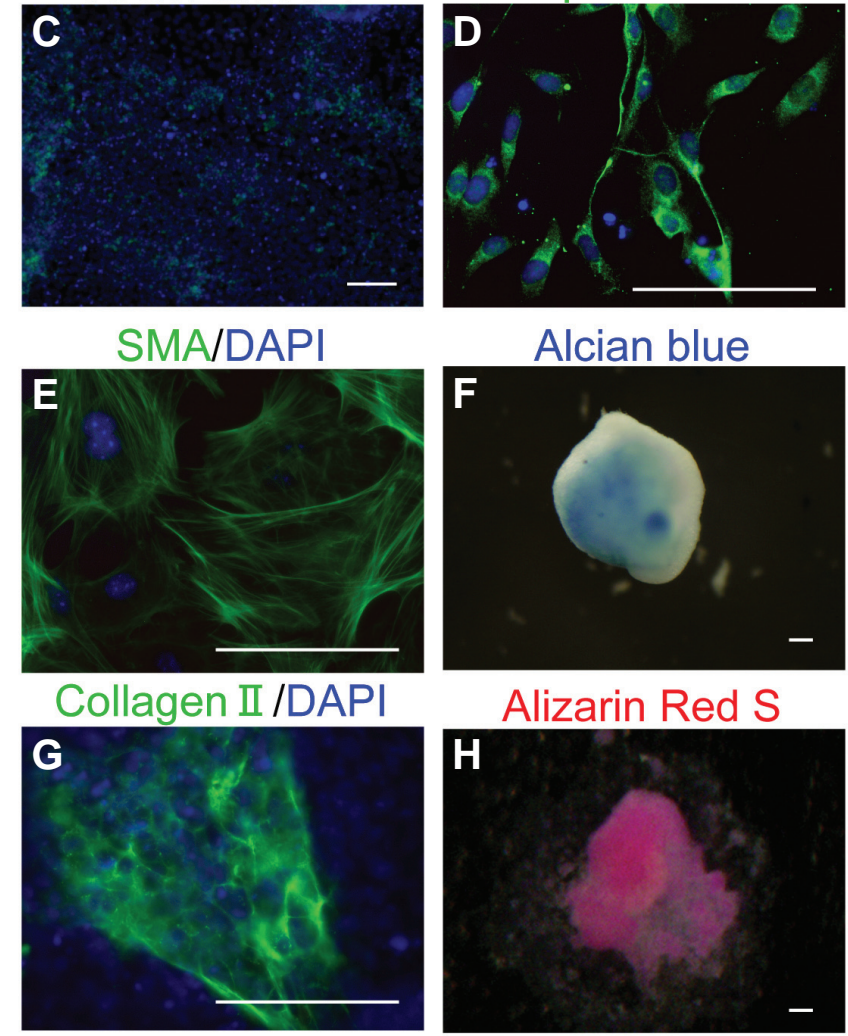

Hoxa2/Collagen I /DAP
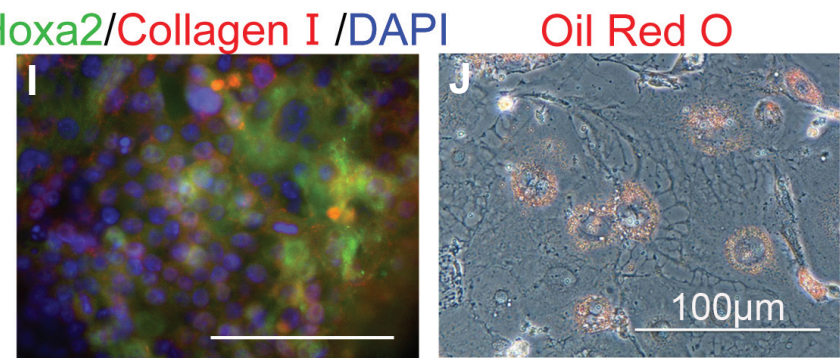
(Fig. 6A) among the cell clones that coexpressed P0-Cre and EGFP genes with Oct-4 and Nanog (data not shown); this clone was designated as P0-6 cells. We then tried to induce NC cells from P0-6 cells using our protocol with FGF-2 and BMP-4. As the cell growth of P0-6 was slow, the differentiation into NC cells was also slow. After 14 days of culture, the differentiated P0-6 cells were positive for direct EGFP-fluorescence under the culture conditions for NC induction (Fig. 6 B,C). There were few EGFPpositive cells when the cells were cultured in ESF basal medium supplemented with 10\% FBS (Fig. 6 D,E) or FGF-2 only (Fig. 6 $F, G)$. These results confirmed that NC cells were induced from undifferentiated P0-6 cells by our protocol.

\section{Discussion}

We previously reported that both laminin and fibronectin promote $\mathrm{mES}$ cell differentiation into primitive ectoderm even in the presence of LIF, while type I collagen can support the undifferentiated state of mES cells (Hayashi et al., 2007). This study now shows that laminin is also beneficial for promoting mES cell differentiation into neural cells in the defined medium of ESF5 with FGF-2. Surprisingly, mES cells underwent cell death on type I collagen in the same culture medium. During development, the cells require a proper environment for cell differentiation and apoptotic cell death (Gilbert and College, 2000; Morales et al., 2005), and the present findings suggest that our defined culture condition could mimic the cell differentiation process during early development in vivo.

Recently, there has been accumulating evidence that NC cells express several markers, including AP- $2 \alpha$ and P0 protein. The AP-2 family of transcription factors consists of five members in humans and mice. They are first expressed in the primitive ectoderm, and are also expressed in the emerging NC cells (Eckert et al., 2005). Therefore, we have used the expression of AP-2 $\alpha$ as a first marker of differentiation into NC cells. FGF-2 induces neural cell differentiation from mES cells (McKay, 1997). We have also shown that FGF-2 induces A2B5-positive cells from $\mathrm{mES}$ cells at high frequency (more than $70 \%$ ) in a defined serumfree medium (Furue et al., 2005). This study now reveals that FGF-2 does promote neural differentiation, but by itself is not able to induce AP- $2 \alpha$ expression in mES cells cultured in ESF5. Addition of other factors will be required for the differentiation of mES cells into NC cells.

Several growth factors have been studied for their potential roles in the differentiation of ES cells into NC cells (Basch and Bronner-Fraser, 2006). Among them, BMP is considered a key factor in NC development (Mujtaba et al., 1998; Molne etal., 2000; Panchision and McKay, 2002). BMP-4 mRNA is homogeneously distributed along the longitudinal extent of the dorsal neural tube (Sela-Donenfeld and Kalcheim, 1999), while inhibiting BMP signaling was proposed to neutralize the ectoderm (Lamb et al., 1993; Sasai et al., 1995; Piccolo et al., 1996; Zimmerman et al., 1996). Rajan et al. (Rajan et al., 2003) further reported that BMP4 regulates neural stem cell differentiation into $\mathrm{NC}$ derivatives by activating a distinct cytoplasmic BMP pathway. However, the present findings indicated that early exposure of FGF-treated cells to BMP-4 did not effectively induce NC cells. Sasai and his colleagues (Kawasaki et al., 2000) reported that early BMP-4 exposure causes epidermogenesis, while in another study, late BMP-4 exposure after the fourth day of coculture with PA6 caused differentiation of NC cells and the dorsalmost CNS cells (Mizuseki et al., 2003). We recently demonstrated that BMP-4 induces trophoblast from undifferentiated mES cells (Hayashi et al., 2010). These findings suggested that early BMP4 exposure in immature neural cells or residual undifferentiated cells induced cell lineages other than NC cells.

P0 protein was originally identified as a Schwann cell-specific myelin protein (Lemke and Chao, 1988; Lemke et al., 1988), but it is also expressed by migrating NC cells during the early embryonic period in chicks (Bhattacharyya et al., 1991). In the P0-Cre/ CAG-CATloxP/--EGFP transgenic mouse, transient activation of the PO promoter induces Cre-mediated recombination, indelibly tagging NC-derived cells with EGFP expression (Yamauchi et al., 1999; Kawamoto et al., 2000; Nagoshi et al., 2008). In a study by Yamauchi et al. (1999), P0-Cre induced EGFP expression was observed in the pharyngeal arches, periocular region, and front nasal region in mouse embryo at E10.5d. In this study, we established an ES-like cell line, P0-6, from P0-
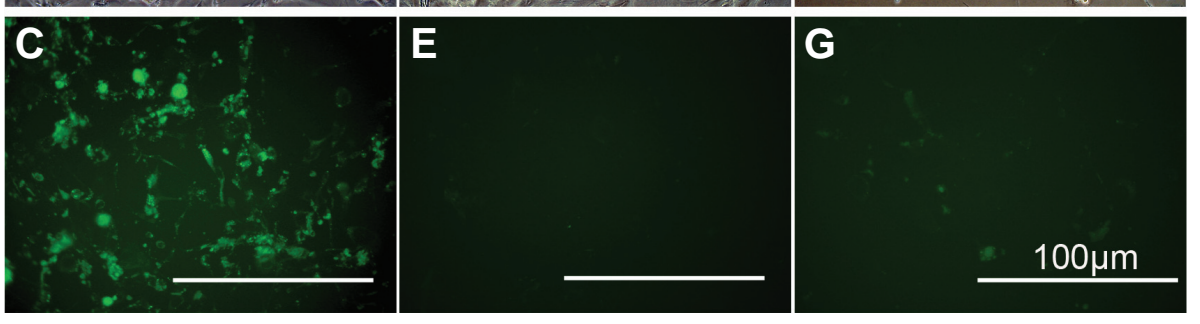
Cre/CAG-CATloxP/-EGFP transgenic mouse blastocysts. When these cells were cultured using the protocol established for inducing NC cells, they expressed EGFP. In the future, studies using a defined serum-free culture system such as ours could be a useful tool for clarifying the mechanisms of NC induction and further differentiation into other lineages.

In conclusion, we have developed a protocol using a defined monolayer culture condition for mES cell differentiation into NC cells. We previously reported that removing LIF from our simple serum-free culture medium consisting of basal medium, LIF, and six other factors resulted in the apoptosis of $\mathrm{mES}$ cells, while removing LIF from the conventional culture medium containing serum induced spontaneous differentiation of mES cells. Ying et al. (Ying et al., 2003) demonstrated that LIF and BMP-4 maintained an undifferentiated state of $\mathrm{mES}$ cells in a medium supplemented with N2 (Bottenstein and Sato, 1979) consisting of five factors (insulin, transferrin, selenium, putrescine, and progesterone), and B27 (Brewer et al., 1993) consisting of 21 factors. However, they recently reported another culture condition using $\mathrm{N} 2$ and inhibitors without B27 (Ying et al., 2008). These findings are consistent with our findings, suggesting that fewer stimulators are beneficial to regulate cell differentiation of mES cells. Our culture condition is useful for elucidating the effects of various exogenous factors on NC cell differentiation. Further, this method could be applied to clinical research, and we are currently adapting this method for human ES and iPS cells.

\section{Materials and Methods}

\section{Cell Culture}

The mouse ES cell line D3 was routinely maintained in ESF7 medium (Cell Science \& Technology Institute, Tokyo, Japan) in $75 \mathrm{~cm}^{2}$ plastic flasks (Corning, New York) coated with type I collagen (Nita Gelatin, Osaka, Japan) in a humidified atmosphere of $5 \% \mathrm{CO}_{2}$ at $37^{\circ} \mathrm{C}$. ESF7 comprises ESF basal medium (Cell Science \& Technology Institute) supplemented with seven defined factors: insulin, transferrin, 2-mercaptoethanol, 2-ethanolamine, sodium selenite, oleic acid conjugated with fatty acid-free bovine serum albumin (FAF-BSA), and $10 \mathrm{ng} / \mathrm{ml} \mathrm{LIF}$, as described previously (Furue et al., 2005; Hayashi et al., 2007; Hayashi et al., 2010).

For differentiation, the cells were inoculated at a density of $5 \times 10^{3}$ cells $/ \mathrm{cm}^{2}$ on laminin-coated plates in ESF5 medium. The ESF5 medium is ESF basal medium supplemented with $10 \mu \mathrm{g} / \mathrm{ml}$ insulin, $5 \mu \mathrm{g} / \mathrm{ml}$ transferrin, $10 \mu \mathrm{M}$ 2-mercaptoethanol, $10 \mu \mathrm{M}$ 2-ethanolamine, and $20 \mathrm{nM}$ sodium selenite (Furue et al., 2005). When the ESF5 medium was supplemented with FGF-2, $100 \mathrm{ng} / \mathrm{ml}$ heparan sulphate (Sigma) was added to the culture medium to enhance FGF-2 activity.

\section{Tdt-mediated dUTP-biotin nick-end labeling (TUNEL) assay and immunostaining}

The cells were subjected to a TUNEL assay using an ApopTag fluorescence direct in situ apoptosis detection kit (Chemicon). After the TUNEL assay, the cells were immunostained with antibodies, as described previously (Hayashi etal., 2010). Briefly, cells were fixed in $4 \%$ (w/ v) paraformaldehyde and permeabilized with $0.1 \%$ Triton $X-100$ or icecold acetone. The cells were then reacted with the following primary antibodies: anti-nestin (1:100; ARP), anti-P0 (1:200; Aves Labs), anti-p75 (1:200; Chemicon), anti-AP-2 $\alpha$ (1:100; Abcam), anti-type II collagen (1:500; Abcam), anti-type I collagen (1:500; Abcam), anti-Hoxa2 (1:100; Santa Cruz Biotechnology), A2B5 (1:100; Chemicon), anti-O4 (1:300; R\&D Systems), anti-peripherin (1:100; Chemicon), anti-Krox-20 (1:200; Covance), and anti-SMA (1:400; Sigma). Primary antibody binding was visualized with AlexaFluor 488-conjugated donkey anti-rabbit IgG (Invitrogen, Carlsbad, CA), AlexaFlu-594-conjugated donkey anti-mouse lgG (Invitrogen). Fluorescence images were acquired using a Nikon fluorescent microscope with a CCD camera (Hamamatsu Photonics) and analyzed with Aquacosmos software (Hamamatsu Photonics).

\section{Real-time RT-PCR}

RT-PCR was performed as described previously (Furue et al., 2005; Hayashi et al., 2007). Briefly, total RNA was extracted from the cultured cells using a total RNA extraction kit (Agilent) and reverse-transcribed using a Quantitect RT kit (Qiagen). Quantitative real-time PCR was performed using SYBR Green PCR Master Mix according to the supplier's directions (Qiagen, Hilden, Germany) with an ABI PRISM 7700 sequence detector (Applied Biosystems, Foster City, CA). The primer sequences are listed in Supplementary Table 1. The relative expression of mRNA was calculated and compared with the expression in each control.

\section{Undifferentiated cell line derived from Protein-0 (P0) promoter-Cre/ Floxed-EGFP transgenic mice}

All experiments in this study were approved by the ethics committees of Keio University and the University of Tokyo, and conducted in accordance with the Guide for the Care and Use of Laboratory Animals of the U.S. Institutes of Health. P0-Cre/Floxed-EGFP double-transgenic mice (ICR background mice) were established as described previously (Nagosh et al., 2008). Blastocysts were collected from 3.5 days after coitus and cultured in DMEM supplemented with $20 \%$ FBS and 1000 unit/mI LIF or ESF7 including 2000 unit/ml LIF supplemented with 5\% FBS on mitomycin-treated primary CF-1 mouse embryonic fibroblasts (MEF feeders; Millipore, Phillipsburg, $\mathrm{NJ}$ ) on a $0.1 \%$ gelatin-coated $35-\mathrm{mm}$ dish in a humidified atmosphere of $5 \% \mathrm{CO}_{2}$ at $37^{\circ} \mathrm{C}$. Each typical ES-like clone was picked up individually, digested by a 27 -gauge needle and passaged. Cell clones expressing both the Cre and EGFP genes were selected and then cultured continuously.

\section{Acknowledgements}

This study was supported by grants-in-aid for Scientific Research from the Ministry of Education, Culture, Sports, Science and Technology of Japan to M. K. F. and M. A., and by an International Cooperative Research Project grant of the Japan Science and Technology Agency to M. A.

\section{References}

BASCH, M.L. and BRONNER-FRASER, M. (2006). Neural crest inducing signals Adv Exp Med Bio/589: 24-31.

BHATTACHARYYA, A., FRANK, E., RATNER, N. and BRACKENBURY, R. (1991). $P 0$ is an early marker of the Schwann cell lineage in chickens. Neuron 7: 831844.

BOTTENSTEIN, J.E. and SATO, G.H. (1979). Growth of a rat neuroblastoma cell line in serum-free supplemented medium. Proc Nat/Acad Sci USA76: 514-517.

BREWER, G.J., TORRICELLI, J.R., EVEGE, E.K. and PRICE, P.J. (1993). Optimized survival of hippocampal neurons in B27-supplemented Neurobasal, a new serum-free medium combination. JNeurosci Res 35: 567-576.

ECKERT, D., BUHL, S., WEBER, S., JAGER, R. and SCHORLE, H. (2005). The AP 2 family of transcription factors. Genome Bio/6: 246.

FURUE, M., OKAMOTO, T., HAYASHI, Y., OKOCHI, H., FUJIMOTO, M., MYOISHI, Y., ABE, T., OHNUMA, K., SATO, G.H., ASASHIMA, M. etal. (2005). Leukemia inhibitory factor as an anti-apoptotic mitogen for pluripotent mouse embryonic stem cells in a serum-free medium without feeder cells. In vitro Cell Dev Biol Anim 41: 19-28.

FURUE, M. and SAITO, S. (1998). Hepatocyte growth factor regulates activin bA mRNA in submandibular gland. In vitro Cell. Dev. Biol. 34: 520-523.

FURUE, M.K., NA, J., JACKSON, J.P., OKAMOTO, T., JONES, M., BAKER, D. HATA, R., MOORE, H.D., SATO, J.D. and ANDREWS, P.W. (2008). Heparin promotes the growth of human embryonic stem cells in a defined serum-free 
medium. Proc Natl Acad Sci USA 105: 13409-13414.

GILBERT, S. and COLLEGE, S. (2000). Cell-cell communication in development. In Dev Biol, (ed. SINAUER, A.). Sinauer Association, Inc, Sunderland, MA, USA, pp.143-181.

HAYASHI, I. and SATO, G.H. (1976). Replacement of serum by hormones permits growth of cells in a defined medium. Nature 259: 132-134.

HAYASHI, Y., FURUE, M.K., OKAMOTO, T., OHNUMA, K., MYOISHI, Y., FUKUHARA, Y., ABE, T., SATO, J.D., HATA, R. and ASASHIMA, M. (2007). Integrins regulate mouse embryonic stem cell self-renewal. Stem Cells 25 : 3005-3015.

HAYASHI, Y., FURUE, M.K., TANAKA, S., HIROSE, M., WAKISAKA, N., DANNO, H., OHNUMA, K., OEDA, S., AIHARA, Y., SHIOTA, K. et al. (2010). BMP4 induction of trophoblast from mouse embryonic stem cells in defined culture conditions on laminin. In vitro Cell Dev Biol Anim 46: 416-430.

KAWAGUCHI, J., MEE, P.J. and SMITH, A.G. (2005). Osteogenic and chondrogenic differentiation of embryonic stem cells in response to specific growth factors. Bone 36: 758-769.

KAWAMOTO, S., NIWA, H., TASHIRO, F., SANO, S., KONDOH, G., TAKEDA, J., TABAYASHI, K. and MIYAZAKI, J. (2000). A novel reporter mouse strain that expresses enhanced green fluorescent protein upon Cre-mediated recombination. FEBS Lett 470: 263-268.

KAWASAKI, H., MIZUSEKI, K., NISHIKAWA, S., KANEKO, S., KUWANA, Y., NAKANISHI, S., NISHIKAWA, S.I. and SASAI, Y. (2000). Induction of midbrain dopaminergic neurons from ES cells by stromal cell-derived inducing activity. Neuron 28: 31-40.

LAMB, T.M., KNECHT, A.K., SMITH, W.C., STACHEL, S.E., ECONOMIDES, A.N., STAHL, N., YANCOPOLOUS, G.D. and HARLAND, R.M. (1993). Neural induction by the secreted polypeptide noggin. Science 262: 713-718.

LE DOUARIN, N.M. and DUPIN, E. (2003). Multipotentiality of the neural crest. Curr Opin Genet Dev 13: 529-536.

LEE, G., CHAMBERS, S.M., TOMISHIMA, M.J. and STUDER, L. (2010). Derivation of neural crest cells from human pluripotent stem cells. Nat Protoc 5: 688-701.

LEMKE, G. and CHAO, M. (1988). Axons regulate Schwann cell expression of the major myelin and NGF receptor genes. Development 102: 499-504.

LEMKE, G., LAMAR, E. and PATTERSON, J. (1988). Isolation and analysis of the gene encoding peripheral myelin protein zero. Neuron 1: 73-83.

LENDAHL, U., ZIMMERMAN, L.B. and MCKAY, R.D. (1990). CNS stem cells express a new class of intermediate filament protein. Cel/60: 585-595.

MCKAY, R. (1997). Stem cells in the central nervous system. Science276: 66-71.

MIZUSEKI, K., SAKAMOTO, T., WATANABE, K., MUGURUMA, K., IKEYA, M., NISHIYAMA, A., ARAKAWA, A., SUEMORI, H., NAKATSUJI, N., KAWASAKI, H. et al. (2003). Generation of neural crest-derived peripheral neurons and floor plate cells from mouse and primate embryonic stem cells. Proc Natl $\mathrm{Acad} \mathrm{SCl}$ USA 100: 5828-5833.

MOLNE, M., STUDER, L., TABAR, V., TING, Y.T., EIDEN, M.V. and MCKAY, R.D. (2000). Early cortical precursors do not undergo LIF-mediated astrocytic differentiation. J Neurosci Res 59: 301-311.

MORALES, A.V., BARBAS, J.A. and NIETO, M.A. (2005). How to become neural crest: from segregation to delamination. Semin Cell Dev Bio/16: 655-662.

MORIKAWA, S., MABUCHI, Y., NIIBE, K., SUZUKI, S., NAGOSHI, N., SUNABORI,
T., SHIMMURA, S., NAGAI, Y., NAKAGAWA, T., OKANO, H. et al. (2009). Development of mesenchymal stem cells partially originate from the neural crest. Biochem Biophys Res Commun 379: 1114-1119.

MORIKAWA, Y., ZEHIR, A., MASKA, E., DENG, C., SCHNEIDER, M.D., MISHINA, Y. and CSERJESI, P. (2009). BMP signaling regulates sympathetic nervous system development through Smad4-dependent and -independent pathways. Development 136: 3575-3584

MUJTABA, T., MAYER-PROSCHEL, M. and RAO, M.S. (1998). A common neural progenitor for the CNS and PNS. Dev Bio/200: 1-15.

NAGOSHI, N., SHIBATA, S., KUBOTA, Y., NAKAMURA, M., NAGAI, Y., SATOH, E., MORIKAWA, S., OKADA, Y., MABUCHI, Y., KATOH, H. et al. (2008). Ontogeny and multipotency of neural crest-derived stem cells in mouse bone marrow, dorsal root ganglia, and whisker pad. Cel/ Stem Ce//2: 392-403.

PANCHISION, D.M. and MCKAY, R.D. (2002). The control of neural stem cells by morphogenic signals. Curr Opin Genet Dev 12: 478-487.

PICCOLO, S., SASAI, Y., LU, B. and DE ROBERTIS, E.M. (1996). Dorsoventral patterning in Xenopus: inhibition of ventral signals by direct binding of chordin to BMP-4. Cel/86: 589-598.

RAJAN, P., PANCHISION, D.M., NEWELL, L.F. and MCKAY, R.D. (2003). BMPs signal alternately through a SMAD or FRAP-STAT pathway to regulate fate choice in CNS stem cells. J Cell Biol161: 911-921.

SAKAKIBARA, S., IMAI, T., HAMAGUCHI, K., OKABE, M., ARUGA, J., NAKAJIMA, K., YASUTOMI, D., NAGATA, T., KURIHARA, Y., UESUGI, S. et al. (1996) Mouse-Musashi-1, a neural RNA-binding protein highly enriched in the mammalian CNS stem cell. Dev Bio/176: 230-242.

SASAI, Y., LU, B., STEINBEISSER, H. and DE ROBERTIS, E.M. (1995). Regulation of neural induction by the Chd and Bmp-4 antagonistic patterning signals in Xenopus. Nature 376: 333-336.

SATO, J.D., BARNES, D., HAYASHI, I., HAYASHI, J., HOSHI, H., KAWAMOTO, T., MATSUDA, R., MCKEEHAN, W.L., MATSUZAKI, K., OKAMOTO, T. et al. (2002). Specific cells and their requirements. In Basic Cell Culture: A Practical Approach, 2nd Edn.,, (ed. J.M. DAVIS). Oxford University Press, Oxford, England., pp.pp. 227-274.

SELA-DONENFELD, D. and KALCHEIM, C. (1999). Regulation of the onset of neural crest migration by coordinated activity of BMP4 and Noggin in the dorsa neural tube. Development 126: 4749-4762.

YAMAUCHI, Y., ABE, K., MANTANI, A., HITOSHI, Y., SUZUKI, M., OSUZU, F., KURATANI, S. and YAMAMURA, K. (1999). A novel transgenic technique that allows specific marking of the neural crest cell lineage in mice. Dev Bio/212: 191-203.

YING, Q.L., NICHOLS, J., CHAMBERS, I. and SMITH, A. (2003). BMP induction of Id proteins suppresses differentiation and sustains embryonic stem cell selfrenewal in collaboration with STAT3. Cel/115: 281-292.

YING, Q.L., WRAY, J., NICHOLS, J., BATLLE-MORERA, L., DOBLE, B., WOODGETT, J., COHEN, P. and SMITH, A. (2008). The ground state of embryonic stem cell self-renewal. Nature 453: 519-523.

ZHOU, Y. and SNEAD, M.L. (2008). Derivation of cranial neural crest-like cells from human embryonic stem cells. Biochem Biophys Res Commun 376: 542-547.

ZIMMERMAN, L.B., DE JESUS-ESCOBAR, J.M. and HARLAND, R.M. (1996). The Spemann organizer signal noggin binds and inactivates bone morphogenetic protein 4. Cel/86: 599-606. 


\section{Further Related Reading, published previously in the Int. J. Dev. Biol.}

See our recent Special Issue Placenta edited by Joan S. Hunt and Kent L. Thornburg at: http://www.ijdb.ehu.es/web/contents.php?vol=54\&issue=2-3

Neural crest ontogeny during secondary neurulation: a gene expression pattern study in the chick embryo Liliana Osório, Marie-Aimée Teillet, Isabel Palmeirim and Martin Catala

Int. J. Dev. Biol. (2009) 53: 641-648

Mouse G-protein gamma3 expression in the developing CNS and neural crest cell derivatives Gregory M. Kelly, Yukio Saijoh, Ariel Finkielsztein and Steve Mangos

Int. J. Dev. Biol. (2008) 52: 1143-1150

Fate of cranial neural crest cells during craniofacial development in endothelin-A receptor-deficient mice Makoto Abe, Louis-Bruno Ruest and David E. Clouthier Int. J. Dev. Biol. (2007) 51: 97-105

The instability of the neural crest phenotypes: Schwann cells can differentiate into myofibroblasts Carla Real, Corinne Glavieux-Pardanaud, Pierre Vaigot, Nicole Le Douarin and Elisabeth Dupin Int. J. Dev. Biol. (2005) 49: 151-159

Regulation of neural crest cell populations: occurrence, distribution and underlying mechanisms $\mathrm{J} L$ Vaglia and B K Hall Int. J. Dev. Biol. (1999) 43: 95-110
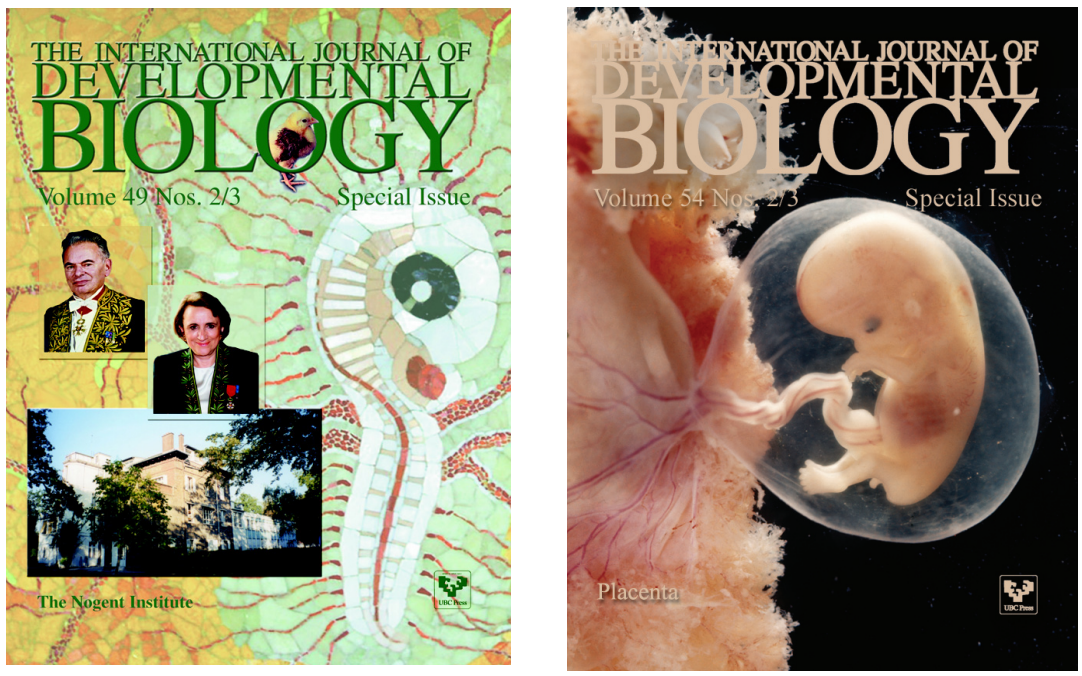

5 yr ISI Impact Factor $(2009)=3.253$
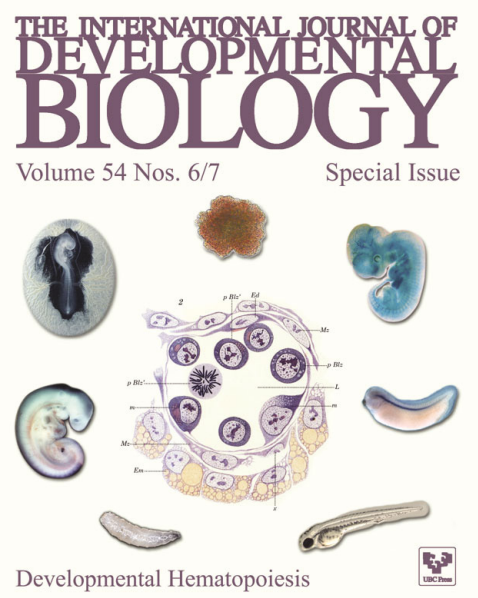